\title{
Man's Capacity of Sustenance within the Walls of his Woes: A Study of Kafka's The Castle
}

\author{
Dr. Sohail Ahmed
}

\author{
Aligarh College of Education, Aligarh, India
}

\begin{abstract}
Keywords - hostile, pain, fatigue, boredom, loneliness, anxiety, good, evil, absurdity, mystery, fatigue, betrayal, suffering, trickery, faith, suspicion, truth, falsehood, complicated, miserable.
\end{abstract}

The Castle is one of the important novels of Franz Kafka, a radical, revolutionary German novelist. The picture of man that Kafka presents or portrays in his novels like 'The Castle', 'The Trial' and 'America' is not the picture of the spiritual or the ideal man but of the real one who lives in the midst of his 'situations' - mostly painful, perilous situations.

Kafka found the world hostile and incomprehensible. And it was therefore, that he had little faith in the absolute values of life. He defended both faith and suspicion, truth and falsehood, good and evil for survival, in a complicated, monotonous, miserable world. We see K., the central character of the novel, defending the cunningness of Frieda, her lies and her betrayals, her whisperings and her malicious ways of keeping secrets:

"She (Frieda) sat there in the taproom like a spider in its web, with all the threads under her control, threads of which no one knew but she; it would have been quite impossible to winkle her out against her will, only love for some lowly person, that is to say, something that was not in keeping with her position, could drive her from her place." (p.272)

What K. wishes to point out to us in the aforesaid passage is that even a wretched, plain, old, skinny, deceitful girl of the taproom like Frieda could be humane and sympathise with the lowly persons. Besides, she could also prove herself extraordinarily beautiful by her dress, manners and sense of duty. So a deceitful girl like Frieda is not despicable. Frieda's beauty emanated from her deceitfulness, from the artful way she did her work. Frieda's vices are, indeed, virtues of a chaotic world. By being truthful and honest or by 'being excessively pleasant' like Pepi, one only bothers and repels others. What is necessary for us, therefore, in chaotic situations is to keep our balance, our cool, our calm and composure after the fashion of Frieda. It is not for nothing that $\mathrm{K}$. praises Frieda:

"We had both striven too intensely, too noisily, too childishly, with too little experience, to get something that for instance with Frieda's calm and Frieda's matter-offactness can be got easily and without much ado. We have tried to get it by crying, by scratching, by tugging - just as achild tugs at the table cloth, gaining nothing, but only bringing all the splendid things down on the floor and putting them out of its reach for ever." (p. 293)

In the passage stated above $\mathrm{K}$. is talking to Pepi, another girl of the tap-room. He is talking about his own strivings and efforts, about his own predicaments and also of Pepi's. He feels repentant at the inadequacy of his knowledge and experience. After suffering and suffering exquisitely $\mathrm{K}$. becomes conscious of the mystery and absurdity of life. He realises that pain, fatigue, boredom, loneliness and anxiety are inevitable parts of human existence and that these things are desirable rather than things to be dreaded. Kafka takes the boredom and pain of life quite objectively, dispassionately. He does not indulge in soapy sentimentalism when he observes:

"Of course all that useless standing about and waiting all day, and day after day, and going on and on without any prospect of a change, must break a man down and make him unsure of himself and in the end actually incapable of anything else but this hopeless standing about." (p. 213) Though Kafka talks about the absurdity of life - 'about useless standing about and waiting all day', he does also talk about the mysterious divine power whose working or whose rules and regulations are beyond human understanding. Kafka urges upon us to cultivate humility in the face of the great mystery enveloping our existence. He reminds us that there is nothing more inadequate than our scholastic argument about the existence of God. K. gets the appointment of the land surveyor. But he does not perform the duties of the land surveyor. He gets the wages without doing any work. Initially he considers Klamm's appreciation of his work - of his land surveying work as his insult or humiliation. But somehow or other he comes to realise:

"It is the stars,

The stars above us that govern our conditions." (King Lear)

We have to endure pain and put up with the absurdity of life quite patiently:

"Men must endure their going hence

Even as their coming hither 
Ripeness is all." (King Lear)

Kafka had no regard or respect for the authority. He was rebellious, full of revolutionary zeal. Yet he managed to contrive in his own way that it is hardly sane or proper for man to take a dismal view of life for it is full of possibilities - both good and evil. Ordinary man is the struggling and suffering individual. Man foolishly leads a riotous life and consequently suffers. His suffering is immense; he is almost helpless within the walls of his woes. And yet he lives and likes living. There is sustenance in spite of suffering. $\mathrm{K}$ is insulted by the school janitor, by the coachman. But he is also loved and appreciated by Hans whom he cures and by Frieda and Pepi - the girls of the tap-room. K. lives in a complicated world. And hence he can't help loving and hating at the same time. Both K. and Hans have the feeling that the apparent facts of existence are not final, that there is a great mystery behind the veil to which man must be awakened. K. is a strange sort of man. He has somehow a feeling that he is destined for something higher, and in the light of this feeling sufferings appear to him as almost insignificant. K. finds himself in a predicament. And the picture of a useless life (for Kafka talks about useless standing about and waiting all day) that he portrays in the novel reminds us of Milton's famous sonnet, "On His Blindness":

"God doth not need

Either man's work, or His own gifts: who best

Bear His mild yoke, they save Him best: His state

Is Kingly; thousands at His bidding speed

And post over land and ocean without rest.

They also serve who only stand and wait."

Kafka seems to be Miltonic in his attitude to and view of life. He did realise that one of the wonderful lessons that life teaches us is patience. By 'uselessly standing about and waiting all day' also we can serve God. And perhaps that may prove to be the best kind of service to God.

In "Stray Birds", Rabindranath Tagore says, 'I have suffered and despaired and known death and I am glad that I am in this world.' (323) This is precisely what Kafka tells us about $\mathrm{K}$. in "The Castle". $\mathrm{K}$. is not influenced by anybody. He thinks independently and his decisions are free decisions based on his experiences.

Kafka does not believe in the absolute moral code but in the philosophy of reconciliation, for man's true nature can be discovered in his wholeness - in the consciousness of his whole - the source of infinite possibilities. Man, he thinks, is a highly privileged creature with power to move up to the Deity, on the one hand and to resolve himself into matter.

K. learns from Frieda that one should not only have disregard for authority one should also be deferential to it. When the situation is incomprehensible or chaotic, openness does not pay so much as a vague gesture or whispering does:

"Her (Freida's) pleading did not penetrate to Klamm. But spider that she was she had connections of which nobody knew. If Pepi said something to a guest, she said it openly; the next table could hear it too. Frieda had nothing to say, she put the beer on the table and went, there was only the nestling of her silk petticoat, the only thing on which she spent money. But if she did for once say something, then not openly, then she whispered it to the guest, bending low so that people at the next table picked up their ears..................she had connexions, she supported the ones by means of the others." (P.286) It is through her connections with Frieda that K. makes himself worthy of her. One can live and survive in this cruel, crooked world only by preserving or maintaining connections. A man or a woman without connection or without influence is bound o be miserable.

Kafka is a practical thinker. He does not believe in any rigid ideology or philosophy. He accepts everything that life offers - good and evil. His mind is far more supple than rigid:

"The only way out does, in fact, lie in the opposite direction, not in greater rigidity but in greater suppleness." (Practical Criticism: I. A. Richards)

We have no other way of sane living than the acceptance - the whole hearted acceptance of the whole man with his infinite possibilities of good and evil. This is because our century, as I. A. Richards tells in 'Practical Criticism', is in "a cultural trough rather than upon a crest." Kafka was not a dogmatic thinker. He was interested in many things. He had a Donne like mind which took pleasure in amalgamating several things and in experiencing ecstasy and anguish, victory and defeat, pride and humiliation, belief and disbelief simultaneously.

$\mathrm{K}$. is a tragic character. He has the capacity to pass through the wheel of fire. He does not run away from the castle unless he discovers that ambition finds sole satisfaction in work. He feels unmanageably tired due to his useless standing about and waiting and yet he stays on in the castle tenaciously. He discovers the desirability of pain in life. To $\mathrm{K}$, life is a painful affair, a burden to bear, a state in which there is much to be endured and little to be enjoyed. Life to him is fraught with fatigue, loneliness, betrayal, suffering, anxiety, trickery, lies and falsehood and it is in such a state that he wants to live authentically.K questions the relevance of the rules of the castle. He discovers that the rules of the castle are based on the whims or caprices of Klamm rather than on reason and good sense. Klamm is in the habit of working arbitrarily. K symbolises the spirit of revolt. He simply wants to emancipate himself from the grip of too much idealism. He realises the harsh reality of his existence in 
the midst of his helplessness, his inability to seek a permit in the middle of the night. K's assertion that he is the land surveyor is a matter of suspicion for the young man of the castle. The young man insists on the official confirmation. $\mathrm{K}$ naturally feels isolated or lonely in the village. $\mathrm{H}$ looks here and there and strives and struggles for support but support or help becomes for him just a point on the receding horizon. It does not come to him easily. $\mathrm{K}$ reflects on the pathos of human isolation and on man's never ending quest for freedom and responsibility in the vast universe. He stands for the philosophy of life which Jean Paul Sartre states thus:

"Man cannot will unless he has first understood that he must count on no one but himself; that he is alone, abandoned on earth in the midst of his infinite responsibilities, without help, with no other aim than the one he sets himself, with no other destiny than the one he forges for himself on this earth."

K's world is not a traditional or conventional world of absolute moral code. It is a very strange, awkward world where people do not know what gratefulness or thankfulness means. He reminds us of Keats:

"Do you not see how necessary a World of Pains and troubles is to school an Intelligence and make it a Soul? A Place where the heart must feel and suffer in a thousand diverse ways!"

\section{REFERENCES}

Kafka, Franz. The Castle. NY: Oxford University Press, 2009

Tagore, Rabindranath. Stray Birds. New York: The Macmillan Company, 1916

Richards, I.A. Practical Criticism. London: Routledge, 2004

Keats on "The Vale of Soul-Making"

Sartre, Jean Paul: Lecture on Existentialism, 1946

Shakespeare, William. King Lear

Milton, John: On His Blindness 